\section{Current role of transient elastography in the management of chronic hepatitis B patients}

Jung Hwan Yu, Jung II Lee

Department of Internal Medicine, Yonsei University College of Medicine, Seoul, Korea

Liver fibrosis is an important prognostic factor for chronic hepatitis $\mathrm{B}(\mathrm{CHB})$, and accurate evaluation of the stage of liver fibrosis is crucial in establishing management strategies. While liver biopsy is still considered the gold standard for staging liver fibrosis or cirrhosis, transient elastography (TE), a noninvasive means of assessing liver fibrosis, has come to play an increasing role in this process. After extensive validation, TE is now regarded as a reliable surrogate maker for grading the severity of liver fibrosis in CHB patients. It can detect the extent of fibrosis in a patient and can also be used to evaluate longitudinal changes in liver fibrosis over time with or without interventional management, such as antiviral therapy. However, several confounders hinder the effective assessment of liver fibrosis using $T E$, such as extensive liver necroinflammation, hepatic congestion, and cholestasis. TE has limited use in obese patients or patients with ascites. Although TE has several limitations, due to its accessibility and safety, it is a valuable tool for the initial evaluation and follow-up in patients with CHB.

Keywords: Elastography; Chronic hepatitis B; Liver cirrhosis

\section{Introduction}

Chronic liver injury of various etiologies may cause the excessive extracellular matrix accumulation, resulting in liver fibrosis [1]. It has generally been accepted that the development of liver cirrhosis, the advanced stage of liver fibrosis, is predictive of increased risks for various complications, as well as liver-associated morbidity and mortality [2]. Moreover, it has been suggested that these risks begin to increase in the very early stages of liver fibrosis [3]. The prognosis of chronic liver diseases, including chronic hepatitis $B$ (CHB) infections, may strongly depend on the degree of liver fibrosis.

CHB is a major causative factor of liver disease globally, affecting approximately 240 million patients and causing 600,000 deaths annually [4]. However, CHB shows a variable spectrum of disease, ranging from inactive hepatitis to progressive hepatitis leading to liver cirrhosis in up to $20 \%$ of patients [5]. The management of CHB depends on the clinical phase of the disease. The severity of liver fibrosis and the extent of liver inflammation are essential factors guiding the treatment of the disease. Although liver biopsy has been the conventional means of evaluating liver inflammation and fibrosis, much progress has been made in the development of noninvasive methods. In this study, we examine transient elastography (TE) and other noninvasive methods for assessing liver fibrosis, and

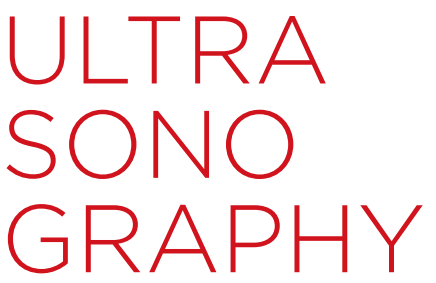

REVIEW ARTICLE

https://doi.org/10.14366/usg. 16023 pISSN: 2288-5919 • elSSN: 2288-5943

Ultrasonography 2017;36:86-94

Received: May 4, 2016

Revised: October 26, 2016

Accepted: October 26, 2016

Correspondence to:

Jung II Lee, MD, PhD, Department of Internal Medicine, Gangnam Severance Hospital, Yonsei University College of Medicine, 211 Eonju-ro, Gangnam-gu, Seoul 06273, Korea

Tel. $+82-2-2019-3310$

Fax. $+82-2-3463-3882$

E-mail: mdflorence@yuhs.ac

This is an Open Access article distributed under the terms of the Creative Commons Attribution NonCommercial License (http://creativecommons.org/ licenses/by-nc/3.0/) which permits unrestricted noncommercial use, distribution, and reproduction in any medium, provided the original work is properly cited.

Copyright (C) 2017 Korean Society of Ultrasound in Medicine (KSUM)

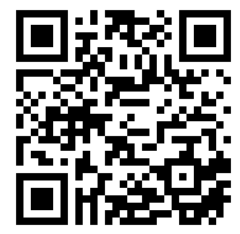

How to cite this article:

$\mathrm{Yu} \mathrm{JH}$, Lee Jl. Current role of transient elastography in the management of chronic hepatitis B patients. Ultrasonography. 2017 Apr;36(2):86-94. 
also discuss the usefulness of TE for follow-up in patients with CHB.

\section{Stages of Chronic Hepatitis B}

The progression of CHB may exhibit several clinical phases: the immune tolerant phase, the immune active phase, the immune control phase, the immune escape phase, and the hepatitis B surface antigen-clearance phase. Individual patients do not necessarily experience these clinical phases in a continuous manner, and these clinical phases are not always correlated with criteria or indications for antiviral therapy $[6,7]$. Hepatitis B virus (HBV) DNA positivity indicates ongoing HBV infection, and negativity indicates resolution of the infection. For this reason, the World Health Organization decided to discontinue usage of the term inactive carrier, replacing it with inactive CHB.

\section{Immune Tolerant Phase}

The immune tolerant phase is characterized by hepatitis $B$ envelope antigen (HBeAg) positivity, high levels of serum HBV DNA (generally $\geq 10^{7} \mathrm{IU} / \mathrm{mL}$ ), normal levels of aspartate transaminase (AST) and alanine transaminase (ALT), and mild or no liver inflammation [8-11]. The phase is especially predominant in cases of perinatal infection. This phase may continue for more than three decades in patients infected with HBV genotype C, which is common among Korean patients, and the rate of spontaneous HBeAg loss is very low [12]. No or mild histologic liver damage is presence despite high levels of HBV DNA due to patients' immune tolerance to HBV [13].

\section{Immune Active HBeAg-Positive CHB}

Most patients in the immune tolerant phase will experience immune responses to HBV as they grow older. The immune active phase is characterized by HBeAg, lower serum HBV DNA levels, and increased or fluctuating ALT levels $[14,15]$. Histologic findings in this phase include moderate to severe liver inflammation and, in some patients, rapid progression of fibrosis [16]. Such changes are due to the enhancement of hepatitis B core antigen or HBeAgspecific cytotoxic T-lymphocyte activity and the resulting destruction of infected hepatocytes [17]. Sustained HBV DNA suppression occasionally accompanies HBeAg seroconversion. However, in many cases, antiviral therapy is needed to suppress viral activity in patients with elevated AST and ALT levels.

\section{Immune Escape $\mathrm{HBeAg}$-Negative $\mathrm{CHB}$}

Approximately $20 \%$ of patients who experience $\mathrm{HBeAg}$ seroconversion during their immune active phase maintain $\mathrm{HBeAg}$ negativity and hepatitis $B$ envelope antibody positivity, resulting in immune escape $\mathrm{HBeAg}$-negative CHB. Immune escape HBeAg- negative CHB involves HBV DNA levels $\geq 2,000 \mathrm{IU} / \mathrm{mL}$, increased ALT levels, and active liver inflammation [18]. These patients show $\mathrm{HBeAg}$ negativity since they harbor HBV variants in the precore or basal core promoter regions of the HBV DNA, resulting in failure to produce $\mathrm{HBeAg}$ [19-21]. HBeAg-negative CHB is associated with low rates of prolonged spontaneous disease remission, and often leads to persistent hepatocellular inflammation, resulting in hepatic fibrosis and cirrhosis [21-23]. Therefore, these patients need antiviral therapy to prevent the progression of hepatic inflammation and fibrosis.

\section{Immune Control Inactive CHB}

Inactive CHB is defined as having persistently normal ALT levels and undetectable levels of serum HBV DNA $(\leq 2,000 \mathrm{IU} / \mathrm{mL})$. The typical histologic findings in this phase are minimal or no liver inflammation, theoretically indicating that no further liver injury can be expected [24].

\section{Liver Biopsy: The Classical Means of Staging Liver Disease}

Although serum biochemical markers such as AST and ALT are very commonly used in assessing the severity of liver inflammation, several recent clinical studies have found that $12 \%-43 \%$ of patients with persistently normal ALT levels had histologic evidence of significant fibrosis or inflammation in a liver biopsy [25-31]. Another retrospective study of the relationship between ALT levels and fibrosis in CHB patients reported similar results: of the 59 patients with persistently normal ALT levels, 18\% had stage 2 fibrosis and $34 \%$ had grade 2 or 3 inflammation, with $37 \%$ of all patients with persistent normal ALT levels having significant fibrosis (stage 2-4) and inflammation [32]. Liver biopsy may not be required in patients with clinical evidence including indicators for the initiation of antiviral therapy irrespective of the grade of inflammation activity or the stage of fibrosis. However, in some cases, it may be necessary to assess the severity of liver disease using means other than biochemical markers.

Liver biopsy has been considered the gold standard method for evaluating the degree of necroinflammation and fibrosis in patients with CHB. It provides information crucial for determining the management of HBV patients, including whether antiviral therapy should be commenced. Treatment should be considered if a liver biopsy reveals fibrosis at stage 2 or greater and/or necroinflammation. Although liver biopsy is an invasive procedure, the rate of serious complications is very low, ranging from $1 / 4,000$ to $1 / 10,000$ [33]. However, the diagnostic accuracy of liver biopsies is often limited by sampling variability, since the average length of 
the biopsy core is $15 \mathrm{~mm}$, which represents approximately $1 / 50,000$ of the size of the entire liver [34]. In addition, it has been reported that significant interobserver variability may take place in histologic assessments, even among very specialized pathologists [33].

\section{Transient Elastography}

TE using FibroScan (EchoSens, Paris, France) is a representative and noninvasive method of assessing liver fibrosis with the advantages of acceptable accuracy and reproducibility. It is performed with an ultrasound transducer probe that produces vibrations of mild amplitude and low frequency. This induces an elastic shear wave that propagates through the liver tissue. The velocity of the shear wave is directly related to liver tissue stiffness (LS); the harder the tissue is, the faster the shear wave propagates (Fig. 1) [35]. The outcome is expressed as a pressure in kilopascals ( $\mathrm{KPa}$ ). The examination is painless, rapid, and easy to perform even in outpatient settings [36]. TE has been demonstrated to be a highly reproducible technique in terms of interobserver and intraobserver agreement, with an intraclass correlation coefficient of 0.98 [37]. It has been suggested by the manufacturer and confirmed in many studies that successful measurements should be validated using the following three criteria: (1) at least 10 valid shots, (2) a success rate (ratio of valid shots to the total number of shots) of at least $60 \%$, and (3) an interquartile range (reflecting the variability of measurements) of less than $30 \%$ of the median LS measurement value. LS measurement using TE is considered a failure when no value is obtained after 10 shots of measurement or more [38].

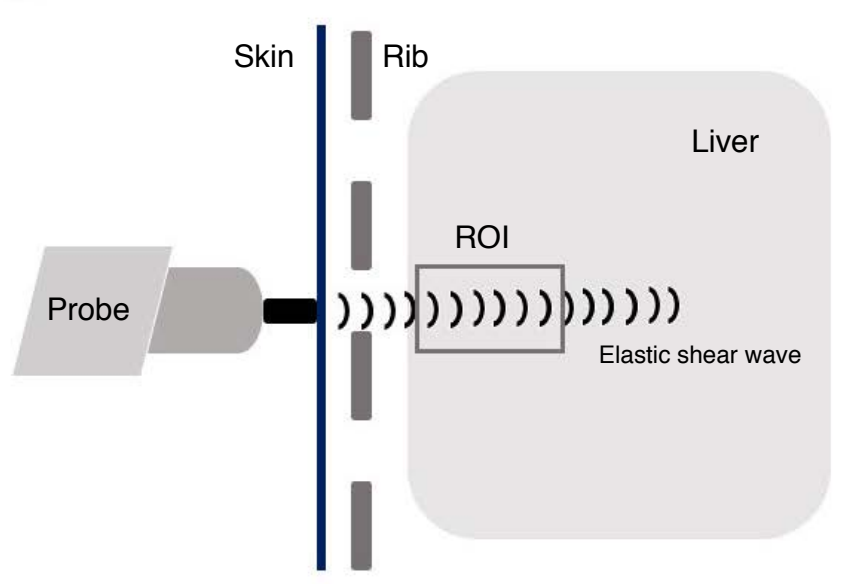

A

Fig. 1. Transient elastography (TE) system.

A. This schematic shows a TE system used for measuring liver stiffness. B. This figure shows TM-mode, A-mode, and elastogram image. The elastogram represents a two-dimensional graphical image of strain rate as a function of depth and time. ROI, region of interest.
Supported by several validations in cross-sectional studies, TE is regarded as a reliable means of evaluating liver fibrosis [39-41]. More recent longitudinal studies assessing changes in liver fibrosis over time or before and after antiviral therapy have indicated that TE can be used to differentiate inactive CHB from active CHB with improved accuracy [42-44].

\section{Normal Values of Liver Stiffness on TE}

Studies examining $L S$ values in apparently healthy subjects reported normal values ranging from 4.8 to $6.9 \mathrm{kPa}[45,46]$. These values were not influenced by age, but higher values were reported in the presence of steatosis or components of metabolic syndrome.

\section{TE in Inactive CHB}

Inactive CHB is defined as undetectable serum HBV DNA $(\leq 2,000$ $\mathrm{IU} / \mathrm{mL}$ ) with persistently normal ALT levels, indicating that no liver inflammation persists in this setting [47]. However, distinguishing true inactive CHB from active CHB with relatively normal ALT levels is not always straightforward. A study reported that $37 \%$ of all patients with persistently normal ALT levels had significant fibrosis and inflammation [32]. TE may be helpful in identifying inactive CHB patients with relatively normal livers. Several studies reported that inactive CHB patients with preserved liver parenchyma showed LS values comparable with those of healthy subjects. In a prospective study by Oliveri et al. [48], the mean LS value of inactive CHB patients was $4.3 \pm 1.0 \mathrm{kPa}$, whereas that of the healthy subjects was $4.6 \pm 1.2 \mathrm{kPa}$. Maimone et al. [49] performed TE on 125 inactive CHB patients and obtained a mean LS value of $4.8 \pm 1.2 \mathrm{kPa}$, which
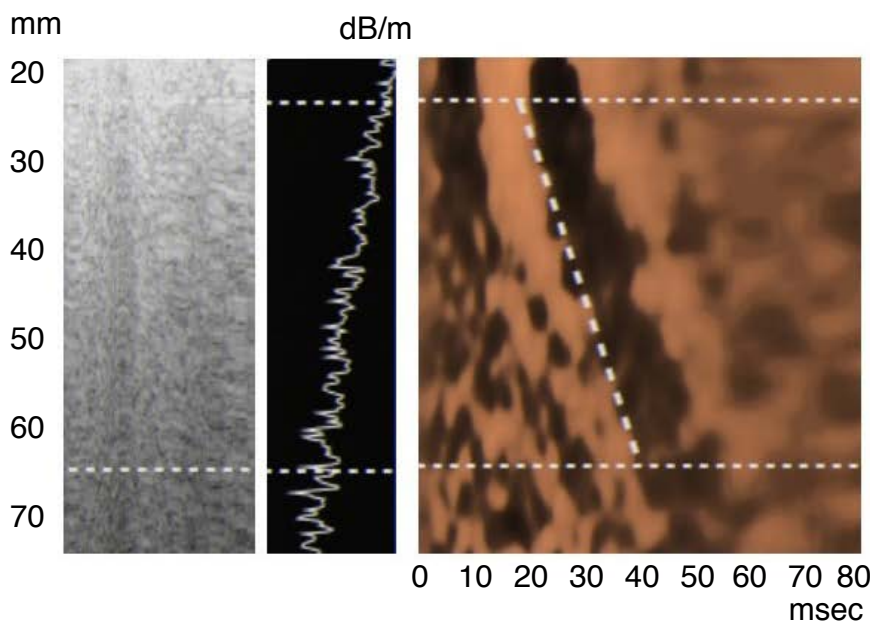

B 
was significantly lower than that of active CHB patients.

A recent longitudinal study reported liver fibrosis progression, detected by increased LS, in only $2.9 \%$ of inactive CHB patients, supporting the definition of inactive CHB [43].

\section{TE in Active CHB and Liver Cirrhosis}

The extent of fibrosis is important, especially in active CHB, given the presence of ambiguous biochemical markers, including mildly elevated ALT levels, which are used to make therapeutic decisions. Several studies have evaluated the diagnostic accuracy of TE in predicting the fibrosis stage in CHB patients. Studies have suggested LS cut-offs ranging from 5.2 to $8.7 \mathrm{kPa}$ in diagnosing significant fibrosis ( $\geq$ grade 2) (Fig. 2) [48,50-55]. The sensitivity estimates ranged from $70 \%$ to $93 \%$, and the specificity estimates ranged from $38 \%$ to $92 \%$. For liver cirrhosis (fibrosis grade 4 ) without significant complications involving portal hypertension, the proposed LS cutoff values varied from 10.3 to $13.4 \mathrm{kPa}$, with sensitivity estimates ranging from $59 \%$ to $100 \%$ and specificity estimates ranging from $79 \%$ to $94 \%[48,50,51,53,55]$.

Although the definition of LS cut-off values that reliably classify patients in a given fibrosis stage is crucial in order to use this technique in practice, a single definition with consistent diagnostic accuracy has not been proposed. Usually, the cut-off value is derived from the receiver operating characteristic curves, and the value optimizing both sensitivity and specificity is chosen. Vigano et al. [53] validated the positive and negative prediction of significant fibrosis

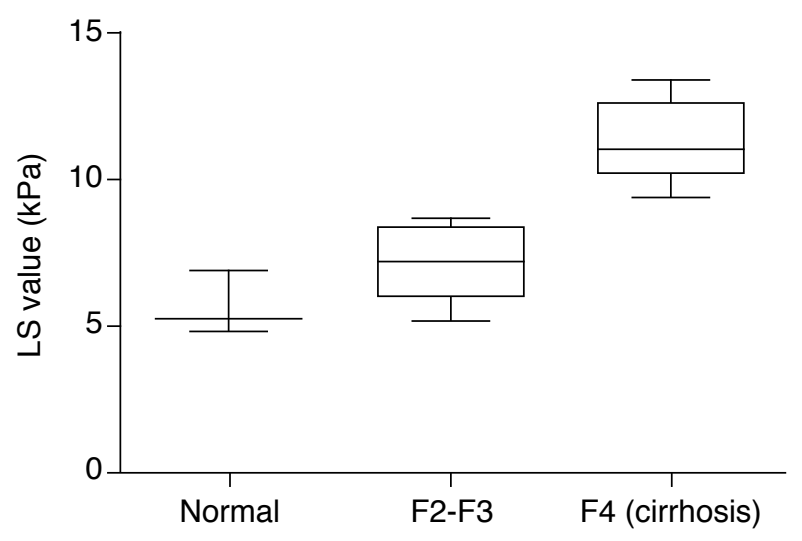

Fig. 2. Distribution of liver stiffness (LS) values according to the severity of liver cirrhosis. This diagram shows LS values in controls, patients with fibrosis grade 2 or $3(F 2, F 3)$, and fibrosis grade 4 (F4). The values were obtained from previous studies. Values for control patients were obtained from references $[45,46]$, the $F 2$ and F3 values were obtained from references $[48,50-55]$, and the F4 values were obtained from references $[48,50,51,53,55]$. and cirrhosis in treatment-naive patients with CHB. Patients were examined by percutaneous liver biopsy, and the LS values of $>13.1$ $\mathrm{kPa}$ and $\leq 9.4 \mathrm{kPa}$ as positive and negative cut-offs for cirrhosis had $>90 \%$ sensitivity and specificity, with an overall predictive power of $94 \%$, independent of ALT values [53].

The LS cut-off may vary according to the etiology of the underlying disease. While most studies have investigated patients with chronic hepatitis $\mathrm{C}(\mathrm{CHC})$, the few studies that have compared $\mathrm{CHC}$ and CHB patients have suggested that LS cut-offs tend to be lower in CHB patients than in CHC patients [54-56].

\section{TE in Monitoring CHB Patients under Antiviral Therapy}

It is beginning to be accepted that fibrosis regression can be achieved in CHB patients by efficiently suppressing the replication of HBV $[57,58]$. Since it is the major prognosis-determining factor in CHB, assessing longitudinal changes in liver fibrosis during antiviral therapy would be very important for establishing CHB treatment strategies. With the introduction of noninvasive means of fibrosis evaluation such as TE, several studies have investigated longitudinal changes in liver fibrosis before, during, and after antiviral therapy $[42,59,60]$.

A study that followed patients treated with either entecavir or lamivudine for 3 years showed that LS values decreased significantly from baseline to 1, 2, and 3 years after treatment (medians, 12.9 $\mathrm{kPa}, 7.5 \mathrm{kPa}, 6.5 \mathrm{kPa}$, and $4.7 \mathrm{kPa}$, respectively; all $\mathrm{P}<0.05$ ) [59].

TE seems to be useful for monitoring changes in fibrosis in patients with CHB receiving antiviral therapy.

\section{Usefulness of TE in CHB Patients with Liver Cirrhosis}

For patients with CHB and liver cirrhosis, the major complications of concern are portal hypertension-related complications, such as esophageal varices, and hepatocellular carcinoma. Many studies have attempted to use TE to predict the probability of these complications. Based on a review of recent papers, higher LS values in TE may be associated with an increased incidence of these complications. Although some discrepancies are present among the papers, a grade can be assigned for the prediction of esophageal varices based on $L S$ values in TE, and it is also possible to predict the extent of portal hypertension and the hepatic venous pressure gradient using $\mathrm{LS}$ values from TE (Table 1).

Therefore, it is thought that CHB patients showing high LS values require more careful follow-up, since they are at a higher risk of complications. Nevertheless, LS values are only for reference, and they should only be used in combination with the results of endoscopy and abdominal ultrasound. 


\section{Considerations in Interpreting TE}

Although $L S$ values from TE are reproducible and relatively reliable, the measured values can be influenced by several factors. Since LS is a physical parameter related to fibrosis, factors that might modify liver elasticity, such as variations in inflammatory infiltrates, parenchymal edema, vascular congestion, cholestasis, and hepatic steatosis can affect the $L S$ values [61-64].

Liver inflammation in CHB patients during hepatitis flare-ups or viral reactivation is known to lead to elevated LS values. It has been demonstrated that the presence of elevated ALT levels can increase $\mathrm{LS}$ values [65].

It is difficult to obtain LS measurements in obese patients, especially those with a body mass index $>28 \mathrm{~kg} / \mathrm{m}^{2}$, and in patients with narrow intercostal spaces, ascites, extrahepatic cholestasis, or congestion $[61,66]$.

Eating before TE may compromise the accuracy of the LS measurements. Theoretically, eating a meal can increase portal blood flow and the hepatic venous pressure gradient, thus increasing liver stiffness [67].

\section{Other Noninvasive Instrumental Techniques}

\section{Magnetic Resonance Elastography}

Magnetic resonance elastography (MRE) is a magnetic resonance imaging (MRI)-based technique that uses a modified phasecontrast method to image the propagative characteristics of a shear wave travelling through the liver [68]. A sound driver is placed on the right upper quadrant of the patient instead of a probe, and the measurements are obtained from the anterior segment of the right lobe. Low-frequency vibrations are emitted, and the MRI spin echo sequence is used to gather data. Mean liver stiffness is expressed in $\mathrm{kPa}$.
MRE has been reported to show excellent accuracy in differentiating significant fibrosis from mild or no fibrosis. The optimally discriminating cutoff MRE value was $4.33 \mathrm{kPa}$ for the diagnosis of cirrhosis in CHB patients, with a sensitivity of $100 \%$ and a specificity of $100 \%$ [69]. The positive predictive value was $91.3 \%$, and the negative predictive value was $100 \%$.

MRE scans cover practically the entire liver and have no limitations in evaluating obese patients or those with ascites. Liver inflammation and elevated ALT do not appear to be associated with MRE values [70]. However, MRE is an expensive and more time-consuming means of evaluation. In addition, patients with claustrophobia or heart pacemakers cannot be evaluated with MRE.

\section{Acoustic Radiation Force Impulse Imaging}

Acoustic radiation force impulse imaging (ARFI) is a sonographybased technique that is an alternative to TE. ARFI mechanically excites tissue for a brief period by delivering a high-intensity acoustic pulse to the region of interest (ROI) [71]. The ROI can be chosen by the operator, and patients with lesions that could interfere with TE measurements can be evaluated using ARFI. The shear-wave velocity (SWV) is recorded in meters per second $(\mathrm{m} / \mathrm{sec})$, and increases with stiffness. ARFI SWV diagnosis cutoff values for CHB patients have not been definitively established, although several studies have reported cutoff values for cirrhosis of $1.75-2.00 \mathrm{~m} / \mathrm{sec}[72,73]$.

ARFI may be useful in patients with lesions that would interfere with LS measurements. However, not many validation studies have been performed and the range of the reported cut-off values is wide $(0.5-4.4 \mathrm{~m} / \mathrm{sec})$, limiting the clinical usefulness of ARFI. It is also less efficient in obese patients [74].

\section{Real-Time Elastography}

Real-time elastography (RTE) uses a modified version of standard

Table 1. Usefulness of liver stiffness measurements obtained using TE in patients with cirrhosis of the liver

\begin{tabular}{|c|c|c|c|}
\hline & & Cut-off (kPa) & Study \\
\hline \multirow[t]{2}{*}{ Esophageal varices } & $>$ Grade 1 & $21.5-31$ & $\begin{array}{l}\text { Castera et al. [75], } 2009 \\
\text { Sporea et al. [76], } 2011\end{array}$ \\
\hline & $>$ Grade 2 & $19.8-47.2$ & $\begin{array}{l}\text { Nguyen-Khac et al. [77], } 2010 \\
\text { Sporea et al. [76], } 2013 \\
\text { Castera et al. [75], } 2009\end{array}$ \\
\hline \multirow[t]{2}{*}{ Portal hypertension } & $\mathrm{HPVG} \geq 10 \mathrm{~mm} \mathrm{Hg}$ & $13.6-21$ & $\begin{array}{l}\text { Vizzutti et al. [78], } 2007 \\
\text { Bureau et al. [79], } 2008 \\
\text { Reiberger et al. [80], } 2012 \\
\text { Salzl et al. [81], 2014 }\end{array}$ \\
\hline & $\mathrm{HPVG} \geq 12 \mathrm{~mm} \mathrm{Hg}$ & $17.6-20$ & $\begin{array}{l}\text { Vizzutti et al. [78], } 2007 \\
\text { Reiberger et al. [80], } 2012\end{array}$ \\
\hline
\end{tabular}

TE, transient elastography; HPVG, hepatic portal venous gradient. 
ultrasound equipment and assesses the extent of liver fibrosis. RTE propagates a shear wave through the liver and echo signals are captured in real time [82]. Not many studies have been performed of the usefulness of RTE in CHB patients. A study of 111 CHB patients suggested a liver fibrosis index of $>3.25$ and a $\%$ area of $>28.83 \%$ for the diagnosis of cirrhosis, with $100 \%$ sensitivity and $85.9 \%$ specificity [83]. RTE can be used in patients with ascites or severe obesity. However, RTE requires further clinical validation in order to have practical value in evaluating CHB patients.

\section{Conclusion}

TE is a noninvasive means of evaluating liver fibrosis with high accuracy and reproducibility for the diagnosis of severe fibrosis and cirrhosis. This enables the identification of CHB patients who need immediate interventional management and helps establish practice guidelines.

TE can also effectively assess dynamic changes in CHB patients receiving antiviral therapy and provide useful means of monitoring and assessing the effects of antiviral therapy.

However, the proposed cut-off values for stages of fibrosis overlap for some stages. LS values can be influenced by the degree of liver inflammation, high ALT levels, and hepatic congestion. Furthermore, TE has limited applicability in obese patients or patients with ascites. Therefore, other noninvasive means of evaluating liver fibrosis complementary to TE are expected to be in use in the future.

ORCID: Jung Hwan Yu: http://orcid.org/0000-0001-5672-038X; Jung II Lee: http://orcid.org/0000-0002-0142-1398

\section{Conflict of Interest}

No potential conflict of interest relevant to this article was reported.

\section{References}

1. Friedman SL. Evolving challenges in hepatic fibrosis. Nat Rev Gastroenterol Hepatol 2010;7:425-436.

2. Wong GL. Prediction of fibrosis progression in chronic viral hepatitis. Clin Mol Hepatol 2014;20:228-236.

3. Park BK, Park YN, Ahn SH, Lee KS, Chon CY, Moon YM, et al. Longterm outcome of chronic hepatitis B based on histological grade and stage. J Gastroenterol Hepatol 2007;22:383-388.

4. Terrault NA, Bzowej NH, Chang KM, Hwang JP, Jonas MM, Murad $\mathrm{MH}$, et al. AASLD guidelines for treatment of chronic hepatitis $\mathrm{B}$. Hepatology 2016;63:261-283.

5. Ganem D, Prince AM. Hepatitis B virus infection: natural history and clinical consequences. N Engl J Med 2004;350:1118-1129.
6. Lok AS, McMahon BJ. Chronic hepatitis B. Hepatology 2007;45:507-539.

7. Hoofnagle JH, Doo E, Liang TJ, Fleischer R, Lok AS. Management of hepatitis $B$ : summary of a clinical research workshop. Hepatology 2007;45:1056-1075.

8. Tran TT. Immune tolerant hepatitis B: a clinical dilemma. Gastroenterol Hepatol (N Y) 2011;7:511-516.

9. Lok AS, Lai CL. A longitudinal follow-up of asymptomatic hepatitis B surface antigen-positive Chinese children. Hepatology 1988;8:1130-1133.

10. Chang MH, Hsu HY, Hsu HC, Ni YH, Chen JS, Chen DS. The significance of spontaneous hepatitis $B$ e antigen seroconversion in childhood: with special emphasis on the clearance of hepatitis B e antigen before 3 years of age. Hepatology 1995;22:1387-1392.

11. Hui CK, Leung N, Yuen ST, Zhang HY, Leung KW, Lu L, et al. Natural history and disease progression in Chinese chronic hepatitis B patients in immune-tolerant phase. Hepatology 2007;46:395-401.

12. Livingston SE, Simonetti JP, Bulkow LR, Homan CE, Snowball $M M, C a g l e ~ H H$, et al. Clearance of hepatitis $B$ e antigen in patients with chronic hepatitis $B$ and genotypes $A, B, C, D$, and $F$. Gastroenterology 2007;133:1452-1457.

13. Vierling JM. The immunology of hepatitis B. Clin Liver Dis 2007;11:727-759.

14. Lee PI, Chang MH, Lee CY, Hsu HY, Chen JS, Chen PJ, et al. Changes of serum hepatitis $B$ virus DNA and aminotransferase levels during the course of chronic hepatitis $B$ virus infection in children. Hepatology 1990;12(4 Pt 1):657-660.

15. Lok AS, Lai CL. Acute exacerbations in Chinese patients with chronic hepatitis B virus (HBV) infection. Incidence, predisposing factors and etiology. J Hepatol 1990;10:29-34.

16. McMahon BJ, Holck P, Bulkow L, Snowball M. Serologic and clinical outcomes of 1536 Alaska Natives chronically infected with hepatitis B virus. Ann Intern Med 2001;135:759-768.

17. Tsai $S L$, Chen PJ, Lai MY, Yang PM, Sung JL, Huang JH, et al. Acute exacerbations of chronic type $B$ hepatitis are accompanied by increased $T$ cell responses to hepatitis $B$ core and e antigens. Implications for hepatitis B e antigen seroconversion. J Clin Invest 1992;89:87-96.

18. Hsu YS, Chien RN, Yeh CT, Sheen IS, Chiou HY, Chu CM, et al. Longterm outcome after spontaneous HBeAg seroconversion in patients with chronic hepatitis B. Hepatology 2002;35:1522-1527.

19. Funk ML, Rosenberg DM, Lok AS. World-wide epidemiology of HBeAg-negative chronic hepatitis B and associated precore and core promoter variants. J Viral Hepat 2002;9:52-61.

20. Lok AS, Akarca $U$, Greene $S$. Mutations in the pre-core region of hepatitis $B$ virus serve to enhance the stability of the secondary structure of the pre-genome encapsidation signal. Proc Natl Acad Sci U S A 1994;91:4077-4081.

21. Okamoto H, Tsuda F, Akahane $Y$, Sugai $Y$, Yoshiba M, Moriyama $K$, 
et al. Hepatitis B virus with mutations in the core promoter for an $\mathrm{e}$ antigen-negative phenotype in carriers with antibody to e antigen. J Virol 1994;68:8102-8110.

22. Croagh CM, Bell SJ, Slavin J, Kong YX, Chen RY, Locarnini S, et al. Increasing hepatitis $B$ viral load is associated with risk of significant liver fibrosis in HBeAg-negative but not HBeAg-positive chronic hepatitis B. Liver Int 2010;30:1115-1122.

23. Yoo BC, Park JW, Kim HJ, Lee DH, Cha YJ, Park SM. Precore and core promoter mutations of hepatitis $B$ virus and hepatitis $B$ e antigennegative chronic hepatitis B in Korea. J Hepatol 2003;38:98-103.

24. Martinot-Peignoux $M$, Boyer N, Colombat M, Akremi R, Pham $B N$, Ollivier $S$, et al. Serum hepatitis B virus DNA levels and liver histology in inactive HBsAg carriers. J Hepatol 2002;36:543-546.

25. Kao JH, Wu NH, Chen PJ, Lai MY, Chen DS. Hepatitis B genotypes and the response to interferon therapy. J Hepatol 2000;33:9981002.

26. Keeffe EB, Dieterich DT, Han SH, Jacobson IM, Martin P, Schiff $E R$, et al. A treatment algorithm for the management of chronic hepatitis B virus infection in the United States: 2008 update. Clin Gastroenterol Hepatol 2008;6:1315-1341.

27. Perrillo RP, Lai CL, Liaw YF, Dienstag JL, Schiff ER, Schalm SW, et al. Predictors of HBeAg loss after lamivudine treatment for chronic hepatitis B. Hepatology 2002;36:186-194.

28. Prati D, Taioli E, Zanella A, Della Torre E, Butelli S, Del Vecchio E, et al. Updated definitions of healthy ranges for serum alanine aminotransferase levels. Ann Intern Med 2002;137:1-10.

29. Kariv R, Leshno M, Beth-Or A, Strul H, Blendis L, Kokia E, et al. Reevaluation of serum alanine aminotransferase upper normal limit and its modulating factors in a large-scale population study. Liver Int 2006;26:445-450.

30. Kim HC, Nam CM, Jee SH, Han KH, Oh DK, Suh I. Normal serum aminotransferase concentration and risk of mortality from liver diseases: prospective cohort study. BMJ 2004;328:983.

31. Bonino $F$, Marcellin $P$, Lau GK, Hadziyannis $S$, Jin $R$, Piratvisuth $T$, et al. Predicting response to peginterferon alpha-2a, lamivudine and the two combined for HBeAg-negative chronic hepatitis B. Gut 2007; 56:699-705.

32. Lai M, Hyatt BJ, Nasser I, Curry M, Afdhal NH. The clinical significance of persistently normal ALT in chronic hepatitis B infection. J Hepatol 2007;47:760-767.

33. Bedossa $P$, Dargere $D$, Paradis V. Sampling variability of liver fibrosis in chronic hepatitis C. Hepatology 2003;38:1449-1457.

34. Garcia-Tsao G, Boyer JL. Outpatient liver biopsy: how safe is it? Ann Intern Med 1993;118:150-153.

35. Sandrin L, Fourquet B, Hasquenoph JM, Yon S, Fournier C, Mal

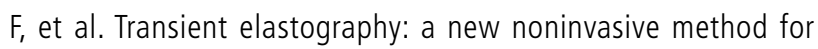
assessment of hepatic fibrosis. Ultrasound Med Biol 2003;29:17051713.

36. Castera L, Forns $X$, Alberti A. Non-invasive evaluation of liver fibrosis using transient elastography. J Hepatol 2008;48:835-847.

37. Fraquelli $M$, Rigamonti $C$, Casazza $G$, Conte $D$, Donato MF, Ronchi $\mathrm{G}$, et al. Reproducibility of transient elastography in the evaluation of liver fibrosis in patients with chronic liver disease. Gut 2007;56:968-973.

38. Castera L, Foucher J, Bernard PH, Carvalho F, Allaix D, Merrouche $W$, et al. Pitfalls of liver stiffness measurement: a 5-year prospective study of 13,369 examinations. Hepatology 2010;51:828-835.

39. Foucher J, Chanteloup E, Vergniol J, Castera L, Le Bail B, Adhoute X, et al. Diagnosis of cirrhosis by transient elastography (FibroScan): a prospective study. Gut 2006;55:403-408.

40. Ganne-Carrie N, Ziol M, de Ledinghen V, Douvin C, Marcellin $P$, Castera $L$, et al. Accuracy of liver stiffness measurement for the diagnosis of cirrhosis in patients with chronic liver diseases. Hepatology 2006;44:1511-1517.

41. Kim DY, Kim SU, Ahn SH, Park JY, Lee JM, Park YN, et al. Usefulness of FibroScan for detection of early compensated liver cirrhosis in chronic hepatitis B. Dig Dis Sci 2009;54:1758-1763.

42. Fung J, Lai CL, Wong DK, Seto WK, Hung I, Yuen MF. Significant changes in liver stiffness measurements in patients with chronic hepatitis B: 3-year follow-up study. J Viral Hepat 2011;18:e200-e205.

43. Wong GL, Chan HL, Yu Z, Chan HY, Tse CH, Wong VW. Liver fibrosis progression is uncommon in patients with inactive chronic hepatitis B: a prospective cohort study with paired transient elastography examination. J Gastroenterol Hepatol 2013;28:1842-1848.

44. Poynard T, Vergniol J, Ngo Y, Foucher J, Thibault V, Munteanu M, et al. Staging chronic hepatitis B into seven categories, defining inactive carriers and assessing treatment impact using a fibrosis biomarker (FibroTest(R)) and elastography (FibroScan(R)). J Hepatol 2014;61:994-1003.

45. Roulot D, Czernichow S, Le Clesiau H, Costes JL, Vergnaud $A C$, Beaugrand M. Liver stiffness values in apparently healthy subjects: influence of gender and metabolic syndrome. J Hepatol 2008;48:606-613.

46. Colombo S, Belloli L, Zaccanelli M, Badia E, Jamoletti C, Buonocore $M$, et al. Normal liver stiffness and its determinants in healthy blood donors. Dig Liver Dis 2011;43:231-236.

47. Korean Association for the Study of the Liver. KASL clinical practice guidelines: management of chronic hepatitis B. Clin Mol Hepatol 2016;22:18-75.

48. Oliveri F, Coco B, Ciccorossi P, Colombatto P, Romagnoli V, Cherubini $B$, et al. Liver stiffness in the hepatitis $B$ virus carrier: a non-invasive marker of liver disease influenced by the pattern of transaminases. World J Gastroenterol 2008;14:6154-6162.

49. Maimone $S$, Calvaruso V, Pleguezuelo $M$, Squadrito $G$, Amaddeo $G$, Jacobs $M$, et al. An evaluation of transient elastography in the discrimination of HBeAg-negative disease from inactive hepatitis B carriers. J Viral Hepat 2009;16:769-774. 
50. Marcellin P, Ziol M, Bedossa P, Douvin C, Poupon R, de Ledinghen V, et al. Non-invasive assessment of liver fibrosis by stiffness measurement in patients with chronic hepatitis B. Liver Int 2009;29:242247.

51. Chan HL, Wong GL, Choi PC, Chan AW, Chim AM, Yiu KK, et al. Alanine aminotransferase-based algorithms of liver stiffness measurement by transient elastography (Fibroscan) for liver fibrosis in chronic hepatitis B. J Viral Hepat 2009;16:36-44.

52. Degos F, Perez $P$, Roche B, Mahmoudi A, Asselineau J, Voitot $H$, et al. Performances of Fibroscan (R) for diagnosis of significant fibrosis and cirrhosis: a prospective study of 1993 patients with chronic viral hepatitis. J Hepatol 2009;50(Suppl 1):S40.

53. Vigano M, Paggi S, Lampertico P, Fraquelli M, Massironi S, Ronchi G, et al. Dual cut-off transient elastography to assess liver fibrosis in chronic hepatitis B: a cohort study with internal validation. Aliment Pharmacol Ther 2011;34:353-362.

54. Verveer $\mathrm{C}$, Zondervan $\mathrm{PE}$, ten Kate FJ, Hansen $\mathrm{BE}$, Janssen $\mathrm{HL}$, de Knegt RJ. Evaluation of transient elastography for fibrosis assessment compared with large biopsies in chronic hepatitis B and C. Liver Int 2012;32:622-628.

55. Cardoso AC, Carvalho-Filho RJ, Stern C, Dipumpo A, Giuily N, Ripault MP, et al. Direct comparison of diagnostic performance of transient elastography in patients with chronic hepatitis $B$ and chronic hepatitis C. Liver Int 2012;32:612-621.

56. Tsochatzis EA, Gurusamy KS, Ntaoula S, Cholongitas E, Davidson $B R$, Burroughs AK. Elastography for the diagnosis of severity of fibrosis in chronic liver disease: a meta-analysis of diagnostic accuracy. J Hepatol 2011;54:650-659.

57. Chang TT, Liaw YF, Wu SS, Schiff E, Han KH, Lai CL, et al. Longterm entecavir therapy results in the reversal of fibrosis/cirrhosis and continued histological improvement in patients with chronic hepatitis B. Hepatology 2010;52:886-893.

58. Dienstag JL, Goldin RD, Heathcote EJ, Hann HW, Woessner M, Stephenson SL, et al. Histological outcome during long-term lamivudine therapy. Gastroenterology 2003;124:105-117.

59. Osakabe K, Ichino N, Nishikawa T, Sugiyama H, Kato M, Kitahara $\mathrm{S}$, et al. Reduction of liver stiffness by antiviral therapy in chronic hepatitis B. J Gastroenterol 2011;46:1324-1334.

60. Ogawa E, Furusyo N, Murata M, Ohnishi H, Toyoda K, Taniai H, et al. Longitudinal assessment of liver stiffness by transient elastography for chronic hepatitis B patients treated with nucleoside analog. Hepatol Res 2011:41:1178-1188.

61. Coco B, Oliveri F, Maina AM, Ciccorossi P, Sacco R, Colombatto $P$, et al. Transient elastography: a new surrogate marker of liver fibrosis influenced by major changes of transaminases. J Viral Hepat 2007;14:360-369.

62. Colli A, Pozzoni P, Berzuini A, Gerosa A, Canovi C, Molteni EE, et al. Decompensated chronic heart failure: increased liver stiffness measured by means of transient elastography. Radiology
2010;257:872-878.

63. Millonig G, Reimann FM, Friedrich S, Fonouni $H$, Mehrabi A, Buchler MW, et al. Extrahepatic cholestasis increases liver stiffness (FibroScan) irrespective of fibrosis. Hepatology 2008;48:17181723.

64. Fraquelli M, Rigamonti C, Casazza G, Donato MF, Ronchi G, Conte $D$, et al. Etiology-related determinants of liver stiffness values in chronic viral hepatitis B or C. J Hepatol 2011;54:621-628.

65. Fung J, Lai CL, Cheng C, Wu R, Wong DK, Yuen MF. Mild-tomoderate elevation of alanine aminotransferase increases liver stiffness measurement by transient elastography in patients with chronic hepatitis B. Am J Gastroenterol 2011;106:492-496.

66. Bamber J, Cosgrove D, Dietrich CF, Fromageau J, Bojunga J, Calliada $F$, et al. EFSUMB guidelines and recommendations on the clinical use of ultrasound elastography. Part 1: Basic principles and technology. Ultraschall Med 2013;34:169-184.

67. Chen J, Talwalkar JA, Yin M, Glaser KJ, Sanderson SO, Ehman RL. Early detection of nonalcoholic steatohepatitis in patients with nonalcoholic fatty liver disease by using MR elastography. Radiology 2011;259:749-756.

68. Muthupillai R, Lomas DJ, Rossman PJ, Greenleaf JF, Manduca A, Ehman RL. Magnetic resonance elastography by direct visualization of propagating acoustic strain waves. Science 1995;269:18541857.

69. Venkatesh SK, Wang G, Lim SG, Wee A. Magnetic resonance elastography for the detection and staging of liver fibrosis in chronic hepatitis B. Eur Radiol 2014;24:70-78.

70. Huwart L, Sempoux C, Salameh N, Jamart J, Annet L, Sinkus R, et al. Liver fibrosis: noninvasive assessment with MR elastography versus aspartate aminotransferase-to-platelet ratio index. Radiology 2007;245:458-466.

71. Nightingale K, Soo MS, Nightingale R, Trahey G. Acoustic radiation force impulse imaging: in vivo demonstration of clinical feasibility. Ultrasound Med Biol 2002;28:227-235.

72. Chen SH, Li YF, Lai HC, Kao JT, Peng CY, Chuang PH, et al. Noninvasive assessment of liver fibrosis via spleen stiffness measurement using acoustic radiation force impulse sonoelastography in patients with chronic hepatitis B or C. J Viral Hepat 2012;19:654-663.

73. Friedrich-Rust M, Buggisch P, de Knegt RJ, Dries V, Shi Y, Matschenz $K$, et al. Acoustic radiation force impulse imaging for non-invasive assessment of liver fibrosis in chronic hepatitis B. J Viral Hepat 2013;20:240-247.

74. Cassinotto C, Lapuyade B, Ait-Ali A, Vergniol J, Gaye D, Foucher J, et al. Liver fibrosis: noninvasive assessment with acoustic radiation force impulse elastography: comparison with FibroScan $\mathrm{M}$ and $\mathrm{XL}$ probes and FibroTest in patients with chronic liver disease. Radiology 2013;269:283-292.

75. Castera L, Le Bail B, Roudot-Thoraval F, Bernard PH, Foucher J, 
Merrouche W, et al. Early detection in routine clinical practice of cirrhosis and oesophageal varices in chronic hepatitis C: comparison of transient elastography (FibroScan) with standard laboratory tests and non-invasive scores. J Hepatol 2009;50:59-68.

76. Sporea I, Sirli R, Popescu A, Bota S, Badea R, Lupsor M, et al. Is it better to use two elastographic methods for liver fibrosis assessment? World J Gastroenterol 2011;17:3824-3829.

77. Nguyen-Khac E, Saint-Leger P, Tramier B, Coevoet H, Capron D, Dupas JL. Noninvasive diagnosis of large esophageal varices by Fibroscan: strong influence of the cirrhosis etiology. Alcohol Clin Exp Res 2010;34:1146-1153.

78. Vizzutti F, Arena U, Romanelli RG, Rega L, Foschi M, Colagrande $S$, et al. Liver stiffness measurement predicts severe portal hypertension in patients with HCV-related cirrhosis. Hepatology 2007;45:1290-1297.

79. Bureau C, Metivier S, Peron JM, Selves J, Robic MA, Gourraud PA, et al. Transient elastography accurately predicts presence of significant portal hypertension in patients with chronic liver disease. Aliment Pharmacol Ther 2008;27:1261-1268.

80. Reiberger T, Ferlitsch A, Payer BA, Pinter M, Schwabl P, Stift J, et al. Noninvasive screening for liver fibrosis and portal hypertension by transient elastography: a large single center experience. Wien Klin Wochenschr 2012;124:395-402.

81. Salzl P, Reiberger T, Ferlitsch M, Payer BA, Schwengerer B, Trauner $M$, et al. Evaluation of portal hypertension and varices by acoustic radiation force impulse imaging of the liver compared to transient elastography and AST to platelet ratio index. Ultraschall Med 2014;35:528-533.

82. Frey H. Realtime elastography: a new ultrasound procedure for the reconstruction of tissue elasticity. Radiologe 2003;43:850-855.

83. Ge L, Shi B, Song YE, Li Y, Wang S, Wang X. Clinical value of realtime elastography quantitative parameters in evaluating the stage of liver fibrosis and cirrhosis. Exp Ther Med 2015;10:983-990. 